\title{
A review on the direct electroplating of polymeric materials
}

\author{
Piotr Augustyn ${ }^{1, *}$ (D), Piotr Rytlewski ${ }^{1}$, Krzysztof Moraczewski $^{1}$, and Adam Mazurkiewicz ${ }^{2}$ \\ ${ }^{1}$ Institute of Materials Engineering, Kazimierz Wielki University, Chodkiewicza 30 Street, 85-064 Bydgoszcz, Poland \\ ${ }^{2}$ Mechanical Engineering Faculty, University of Science and Technology, Kaliskiego 7 Street, 85-796 Bydgoszcz, Poland
}

Received: 11 March 2021

Accepted: 8 June 2021

Published online:

24 June 2021

(C) The Author(s) 2021

\begin{abstract}
This work is a review of the literature on the possibilities for electroplating of polymer materials. Methods of metalizing polymers and their composites were presented and discussed. Information from various publications on the electrical properties of polymers and polymer composites was collected and discussed. The most important results on the electroplating of conductive polymers and conductive composites were presented and compared. This work especially focuses on the electrical conductivity of polymer materials. The main focus was the efficiency of metal electrodeposition. Based on the analyzed publications, it was found that electrically deposited metal layers on conductive polymeric materials show discontinuity, considerable roughness, and different layer thickness depending on the distance from the contact electrode. The use of metal nanoparticles (AgNWs) or nickel nanoparticles (NiNPs) as a filler enables effective metallization of the polymer composite. Due to the high aspect ratio, it is possible to lower the percolation threshold with a low filler content in the polymer matrix. The presented review reveals many of the problems associated with the effectiveness of the electroplating methods. It indicates the need and direction for further research and development in the field of electroplating of polymer materials and modification of their electrical properties.
\end{abstract}

\section{Introduction}

One of the most important groups of materials used in industry, besides metals and ceramics, are polymer materials. The rapid development of their applications results from high resistance to chemical substances, low density, and easy manufacturing of products with complex shapes. The initial research on covering polymeric materials with metal layers can be dated back to the 1950s when the first electroplating baths were developed to enable the

Handling Editor: Maude Jimenez.

Address correspondence to E-mail: augustyn@ukw.edu.pl 
application of copper and nickel coatings [1]. Historically, the first metallic coatings exhibited poor adhesion to the polymeric substrates. The discovery of the poly(acrylonitrile-butadiene-styrene) (ABS) terpolymer made it possible to achieve a large increase in the adhesion of metallic coatings. ABS is a thermoplastic material whose basic phase is acrylonitrile-styrene in which the butadiene phase is dispersed. In this material, selective dissolution of the dispersed butadiene phase with organic solvents can take place. The pores formed in this way increase the contact surface between the substrate and the metal layer, increasing the interphase adhesion [2].

Metallization of polymer materials was initially used as a decorative finishing for details, and with the development of this technology, the range of applications was broadened [3]. Nowadays, metalized plastics are used also in electronics as printed circuits, antennas, connectors, as equipment for cars, airplanes, and ships [4,5]. Metallization of casing surfaces is used in electromagnetic (EM) shielding of electronic devices. A particularly effective method of reducing the level of the electromagnetic field is the use of barriers made of materials characterized by high electrical conductivity. In addition to typical materials (copper, aluminum, brass, steel) used as EM screens, polymer composites, polymer nanocomposites, conductive polymers, or metalized polymers can also be applied [6-10]. An important area of application of the metallization of polymer materials is the MID (Molded Interconnect Devices) technology. Its technological process can be generally divided into two stages: injection molding and application of conductive tracks and solder pads by selective metallization of the material [11]. MID has found application, among others, in the rapid prototyping technology, which allows the production of products directly based on CAD data, without the need for mechanical processing. Such a product can be molded from a thermoplastic material in additive manufacturing (2D/3D). Built-in MID, 2D / 3D technology, switches, resistors, capacitors, printed circuits, etc., can be electrically connected in various geometric configurations. This allows electronic components to be installed in free spaces of devices, for example inside a car lamp, cockpit, or other covered technical product. This solution may reduce the use of structured wiring and reduce control units.

This work is an attempt to find and analyze available information on the metallization of polymers and their composites, with emphasis on electroplating as a method that pollutes the environment to a lesser extent than electroless metallization, which requires using highly harmful chemicals in several stages of the process, e.g., formaldehyde which is a common reducing agent. For economic reasons, there is a need to simplify the metallization process. Also for the sake of ecology and human health, efforts are made to eliminate harmful sensitizing agents. Therefore, it is worth considering why electroplating methods are not implemented on an industrial scale and if this situation can be changed. Introductory, all significant metallization methods of polymer materials were discussed. A distinction has been made between conductive polymers (intrinsic conductors) and conductive polymer composites (extrinsic conductors). Methods of modifying electrical conductivity are discussed for both intrinsic and extrinsic polymers. Finally, the results of the electroplating composites are reviewed and discussed.

\section{Conventional metallization methods}

The problem of metalizing polymers is well known and described in specialized literature. The conventional polymer material is an insulator and it is not possible to electroplate it. Technological development focused on the improvement of chemical and physical methods. These processes are complicated, require specialist, expensive equipment, and the chemicals used in them are often aggressive to the environment and humans. This chapter is intended to generally introduce the existing methods of creating metallic coatings on polymers and to familiarize with the basic problems that occur in this industry. The most commonly used in industry polymers that are metalized can be conventionally divided into three groups, depending on the maximum temperature range of their operation. This division is presented in Table 1.

The knowledge of the working temperatures of polymers is necessary to select the appropriate method of metallization. The most common in industry are electroless methods $[4,5]$, physical metal vapor deposition methods (PVD), and chemical vapor deposition (CVD) where either solid or liquid precursors are used [12-14]. These methods can be briefly characterized as follows: 
Electroless method (also known as chemical metallization). A metal deposition involves the flow of electrons from the more electronegative metal (or a reducing substance) to the metal ions of the deposited metal. This process takes place in the metallization bath without using an external source of power [15]. Electroless methods can be divided into three groups [15-17]: deposition by exchange-metals less noble, more electronegative, replace the more electropositive, and noble from the solution. Deposition only takes place in direct contact between the metallization bath and the surface. After the entire surface is covered, the process stops; deposition by chemical reduction-a reduction from the ionic to metallic state occurs as a result of attaching an appropriate number of electrons to the metal ion. A substance that can donate electrons is called a reducer [18] and autocatalytic-is a kind of metal deposition by reduction. The process takes place in a bath in which metal ions are reduced in the presence of a catalyst. The reaction takes place when the catalyst is in direct contact with the bath and occurs only on the surface of the catalyst, which is the metal that is coated or deposited on the surface of the polymer product [19].

The autocatalytic deposition can be used in the metallization of polymers only if the surface of the material contains active areas resulting from the application of the catalyst [20]. The basic and most frequently used reducing agent in the autocatalytic metallization process is formaldehyde $\left(\mathrm{CH}_{2} \mathrm{O}\right)$. This is a technological problem-the reducer is only effective at high $\mathrm{pH}$ levels $(\mathrm{pH}>11)$, as well as an environmental problem because it is a highly poisonous agent, causes cancer, and is dangerous to the environment [21, 22]. Additionally, an aqueous palladium chloride solution is used during the sensitization step $\left(\mathrm{PdCl}_{2}\right)$. To reduce the number of wet chemicals steps, a one-step procedure has been developed with the use of a colloidal suspension containing $\mathrm{Pd}$ and $\mathrm{Sn}-$ an acidic solution of $\mathrm{SnCl}_{2}$ and $\mathrm{PdCl}_{2}[23,24,25]$. One of the most common metals deposited on the surface of polymers is copper. Due to the high electrical conductivity of $\mathrm{Cu}$, autocatalytic copper plating plays an important role in the industry. The main area of application is in the electronics industry, production of printed circuits, integrated circuits as well as semiconducting structures [20, 26, 27]. The obtained copper layers can be further processed, by electroplating with other metals, such as nickel [23, 24, 25].

PVD methods-The deposited metal is evaporated from the solid or liquid phase as particles. Then these particles in gaseous form are transported to and condensed on the surface of the polymer [24]. These methods make it possible to use pure metals as metallization reactants instead of compounds harmful to humans and the environment. The speed of the deposition process can reach $25 \mu \mathrm{m} / \mathrm{s}$, while the thickness can be from one nano- to several millimeters [28]. Metallic layers obtained by these methods are characterized by high purity, good tribological properties, very high hardness, and high corrosion resistance [29]. However, the disadvantages of these methods are difficulties with the repeatability of the properties for obtained metallic layers, incomplete coverage of the metalized product in surface holes, as well as the price of the equipment, used [30]. A very important process parameter is the adhesion of the metal layer to the polymer substrate. It largely depends on the preparation and cleanliness of the surface of the product. The preparatory process consists of two main steps: chemical surface preparation (removal of all kinds of impurities, e.g., fats, greases) and/or activating the surface layer and heating it [31].

CVD methods-Metal particles are deposited on the surface of the product as a result of the chemical reduction or gas decomposition of a chemical precursor-a chemical compound that occurs or is formed in the first stage of the reaction, and which transforms into another substance in the further course of the phenomenon. Reactions can be initiated either thermally, by irradiation, or by plasma treatment $[25,32]$. The reactions in CVD methods can be divided into decomposition, reduction, and chemical transport reactions [33, 34]. Each of them consists of many stages. These methods require using high temperatures, even as high as $1000{ }^{\circ} \mathrm{C}$ to initiate and maintain chemical reactions, hence the scope of application of this type of method, especially for polymer materials is limited [24, 31]. The rate of deposition of the metal layer depends on the temperature and gas pressure at which the process occurs. The latter parameter plays an important role in the rate of metal deposition-at low pressures, the transport of reactants from the gas phase is practically stopped. On the other hand, the growth rate of the deposited layer depends mainly on the product 
and the gas temperature. CVD methods require a lot of money and research on the properties of the precursors. The simple methods used to determine precursors' properties are thermogravimetric analysis (TG) and differential scanning calorimetry (DSC) [35-37]. The precursors must be of high chemical purity so that the resulting metal layers are free from inclusions of impurities. Therefore, the development of precursor purification methods such as sublimation, distillation, rectification, chromatography, sublimation is frequently applied [25].

Conventional polymers, due to the lack of electrical conductivity, are not suitable for electroplating. However, this technique is used as the next step in the entire coating process. The previously prepared polymer is subjected to the process of metal deposition by physical (PVD) or chemical (CVD or electroless) methods. Then, a metallic coating is created that enables a further electroplating process of the product.

\section{Metallization of conductive polymers}

Finding intrinsically conductive polymers opened the way to research the electroplating of these materials. This chapter briefly describes the types of intrinsically conductive polymers, followed by more significant research results.

\section{Conductive polymers}

Conducting polymers, known as "conjugated polymers," are multi-molecular compounds having a system of conjugated bonds in the main chain. The conduction of electrons takes place along the main polymer chain and is possible due to the presence of conjugated bonds. The mechanism of conductivity is related to the presence of an energetic conduction band resulting from electron delocalization in double bonds. Electrons can be released from one of the conjugated double bonds present in the chain. Elements such as iodine or sodium introduced into the polymer can donate electrons which, being free electrons, contribute to higher conductivity. The application of an external electric field causes the orderly movement of these electrons. Another group of conductive polymers is that in which polymers are compounded with macromolecules containing groups capable of ionically dissociating-or containing groups capable of reversible redox reactions. These reactions involve the exchange of electrons between the electron-donating species (reducing agent) and the electron receiving species (oxidant). Conduction is based on the principle of electron transfer between redox groups [38, 39].

Conducting polymers most commonly described in the literature are polyacetylene (PA), polyaniline (PANi), polypyrrole (PPy), polythiophene (PT), poly(p-phenylene) (PPP), poly(3,4-ethylene dioxythiophene) (PEDOT) [40]. Of all the abovementioned, the group of conjugated polymers is of significant interest due to the special conductivity mechanism and stability in the environment of oxygen and water [41, 40].

Polyacetylene (PAC) - Is a conjugated polymer having various properties, including electrical conductivity (undoped polymer has a conductivity of $10^{-7} \mathrm{~S} / \mathrm{cm}$ ), photoconductivity, gas permeability, and others [42-48]. Doped with iodine, chlorine, and bromine, it has an electrical conductivity $10^{9}$ times greater than without these additives. Its exposure to air changes its properties-from highly elastic they become brittle and lose their silvery shine. These changes are also correlated with a decrease of electrical conductivity $[49,50]$.

Polythiophene (PT) - It belongs to the group of electrically conductive polymers, which in its pure grade has a conductivity of $10^{-9} \mathrm{~S} / \mathrm{cm}$, while after
Table 1 Classification of polymers due to the working temperature

\begin{tabular}{lll}
\hline Maximum working temperature & \\
\hline Under $90{ }^{\circ} \mathrm{C}$ & $100-140{ }^{\circ} \mathrm{C}$ & Over $140{ }^{\circ} \mathrm{C}$ \\
$\mathrm{ABS}$, & Polycarbonate, & Polysulfides, \\
Polystyrene, & Polyimides, & Polyetherimides, \\
Polyethylene, & Polyacetals, & Polysulfones, \\
Polyamides & Polyesters, & Liquid crystal polymers, \\
Polyvinyl chloride, & Some hard polyamides & Fluoro polymers (e.g., Teflon), \\
& & Thermosetting epoxy resins \\
\hline
\end{tabular}


doping, this value increases to $10^{3} \mathrm{~S} / \mathrm{cm}$. It is soluble in many organic solvents, both doped and undoped [51, 52]. Apart from good electrical conductivity, polythiophene shows strong electroluminescence [53].

Polypyrrole (PPy)_Produced in the process of electropolymerization or by chemical synthesis, it has biocompatibility, which enables its application in various types of biosensors $[54,55]$. It can be used for neural implants, biosensors, and molecular memory devices that have an amorphous structure [56]. The electrical conductivity of pure, undoped polypyrrole is in the range from $10^{-9}$ to $10^{-6} \mathrm{~S} / \mathrm{cm}$. Doping with substances such as $\mathrm{AsF}_{5}, \mathrm{SbF}_{3}, \mathrm{AlCl}_{3}, \mathrm{ZrCl}_{5}$ improves its conductivity to the level characteristic for metals.

Poly(p-phenylene) (PPP)— has an electrical conductivity in the range from $10^{2}$ to $10^{3} \mathrm{~S} / \mathrm{cm}[57,58]$. Its electrical properties can be further modified by doping [59]. Polyphenylene derivative-poly(p-phenylene vinyl) shows strong electroluminescent properties and nonlinear optical properties. When the source of current is applied, the polymer emits light (in the range of about 495 to about $589 \mathrm{~nm}$ ). Thanks to these properties, it is used in the construction of OLED (Organic Light-Emitting Diode) displays [58].

Polyaniline (PANi)—is formed as a result of anodic oxidation of aniline in sulfuric acid [60] and characterizes by high electrical conductivity, simple synthesis, and high stability under atmospheric conditions [61]. In its pure grade, it reaches a conductivity of up to $10^{4} \mathrm{~S} / \mathrm{cm}$ [49]. Doped polyaniline has found applications in varnishes and mixtures absorbing microwave radiation. It is an excellent antistatic material, also used in lithium-polymer batteries as electrodes immersed in an electrolyte solution. It has electroluminescent properties; hence, it is used in the production of polymer LEDs and OLED displays. PANi is also used for the production of sensors used in biomaterials [62] or as a matrix for nanocomposites [63, 64].

Poly(3,4-ethylene dioxythiophene) (PEDOT)—Transparent and highly conductive polymer classified to the electrochromic polymers changing its color due to the flow of electric current. With proper control of production conditions, the electrical conductivity of the PEDOT film can be modified in the range from $1 \bullet 10^{-5}$ to $1 \bullet 10^{3} \mathrm{~S} / \mathrm{cm}$ [65]. It was even reported that this polymer has an electrical conductivity of about $4,6 \bullet 10^{3} \mathrm{~S} / \mathrm{cm}$ [66]. It can be applied in the OLED displays, touch panels, lithium-polymer batteries (reversible galvanic cells), organic photovoltaic cells, or as a component for antistatic coatings [58, 65].

Figure 1 shows an overview of the conductivity ranges of conductive polymers. The lower value in the bar of each polymer corresponds to the conductivity value of the unmodified polymer. Similarly, the higher value on the bar corresponds to the conductivity of the polymer after modification. These values were compared with the electrical conductivity of metals such as copper, gold, and silver. It is clear that, except PANi, all other polymers have a value of electrical conductivity several orders of magnitude lower than the indicated metals in Fig. 1. This means a real problem with the electroplating of such material because the intensity of the current flowing through the metalizing solution depends precisely on the electrical conductivity of the electrode to be deposited. This determines the efficiency and speed of the coating process. Most important research of electroplating of intrinsically conductive polymers.

\section{Most important research of electroplating of intrinsically conductive polymers}

Yfantis et al. used PPy as a coating for the metallization of insulators [67]. Samples of ABS and FR4 (glass fiber reinforced epoxy resin) were immersed in $\left(\mathrm{NH}_{4}\right) 2 \mathrm{~S}_{2} \mathrm{O}_{8}$ solution and then an aqueous pyrrole solution was added, which caused chemical polymerization of pyrrole to polypyrrole on the surface of ABS and FR4. Then, the samples prepared were subjected to electroplating deposition in a bath containing copper ions. Results showed that copper was initially deposited in the surface area where the sample was connected to the electrode. Further growth took place faster through the previously deposited copper than through the PPy layer. It was found that although the PPy layer had sufficient electrical conductivity for current deposition, its value was much lower than that of the copper itself, thus coating the polymer surface with a metallic layer was ineffective [67].

Hepel et al. investigated the effect of PPy ion exchange on the deposition of copper and nickel on gold electrodes [68]. In this study, the EQCM (Electrochemical Quartz Crystal Microbalance) technique was used, which enabled monitoring the change in electrode mass related to deposition or ion exchange between the surface layer and the electrolyte. Three types of electrodes were used: a gold electrode 
without a polymer coating, an electrode coated with undoped PPy, and an electrode coated with a mixture of PPy and polystyrene sulfonate (PSS). It has been found that the type and surface properties of the substrate are of great importance for the initial deposition process. The PPy layers obtained by electropolymerization in the presence of ions act like an anion exchange membrane [69]-a semi-permeable membrane designed to transport anions (impermeable to gases such as oxygen and hydrogen). On the other hand, the layer constituting the PPy/PSS mixture, in which the PSS anions have been permanently trapped, acts like a cation-exchange membrane (allowing cations to be transported). $\mathrm{A} \mathrm{CuSO}_{4}$ solution was used in the metallization bath, and metallization was carried out at different voltages within time intervals of $30 \mathrm{~s}$. A higher deposition rate of the copper layer was obtained on the PPy/PSS blend as compared with neat PPy. As a result of the experiment, $4.9 \mu \mathrm{g}$ of copper was deposited on the electrode coated with neat PPy, and about $6.6 \mu \mathrm{g}$ on the electrode coated with PPy/PSS. It was found that copper was not only deposited on the surface but also penetrated inside the pores of the polymer resulting in the formation of the composite PPy/PSS/Cu surface layer.

In the work of Zouaoui et al., the possibility of deposition of copper particles on polypyrrole by electoreductive precipitation from copper complexes was discussed [70]. Polymer layers (polypyrrolealkylammonium) were deposited on the carbon electrodes. The research was carried out using the RDE (Rotating Disk Electrode) method, in which a system of three rotating electrodes is used during the experiment, inducing a stream of metal ions to the electrode [71]. This method is also used in the study of mechanisms related to redox reactions. The amount of introduced metal was estimated based on coulometric measurements. The morphology of polymer layers and the distribution of metal particles using a scanning electron microscope (SEM) were also investigated. It was proved in that article that the nucleation process initially takes place at the interface between the electrode and the polymer. Then growth occurs at the surface of the polymer layer. It has also been shown that the polymer matrix contains welldispersed inclusions particles of copper.

Nichols et al. analyzed the initial stages of copper deposition on the polymer surface [72]. The neat PPy film of about $35 \mu \mathrm{m}$ thickness with electrical conductivity of $150 \mathrm{~S} / \mathrm{cm}$ was coated with gold as an electrode. It has been observed that the nucleation of copper occurs first in places of surface defects, such as at the edges of the deposited polymer layer. In the initial stage, the deposition does not occur on the flat central surface of the sample. The growth of locally deposited copper agglomerates occurs mainly transversely to the substrate surface and leads to full coverage of the surface. It has also been shown that the lower potential is responsible for the growth rate of the metallic layer-more seeds appear.

The electroplating of copper on thin PEDOT layers was also a subject of investigation [73]. The electroplating experiments were performed in a simple, single-chamber electrochemical cell containing a copper foil electrode coated with PEDOT as a working electrode and a reference electrode. $\mathrm{A} \mathrm{CuSO}_{4} /$ $\mathrm{H}_{2} \mathrm{SO}_{4}$ solution was used as the electrolyte. The thickness of the deposited layer was determined using fluorescence spectroscopy. It was noticed that the potential in the polymer layer was not constant but varied along the length of the sample. This resulted in a decrease in copper deposition rate along with the increasing distance from the contact with the electrode. SEM measurements have shown that copper agglomerates are initially formed only in the vicinity of the electrode. Their further growth is dendritic and in the final phase, they combine to form a continuous layer.

Specialist literature in the field of electroplating of conductive polymers does not contain many items. This may be because of unsatisfactory research results. This paper cites the most significant scientific works that present the problem in a complementary way. In the works of Yfantis et al. [67], Zouaoui et al. [70], and De Leeuw et al. [73], similar results were obtained. The formation of a metallic layer was initially formed close to the electrical contact. The effectiveness of metallization decreases with increasing distance from the electrode contact point. This is due to the proportional dependence of the electrical conductivity on the length of the conductive polymer. The electric current has a higher density near the electrical contact and the polymer electrode. Hence, the phenomenon of metallic layer deposition occurs more effectively in the area of electrical contact and disappears as far away from it. Interesting work is the paper by Heppel et al. [68]. It presents the results of PPy metallization and its blend with PPS. It is interesting that the introduction of a conductive 


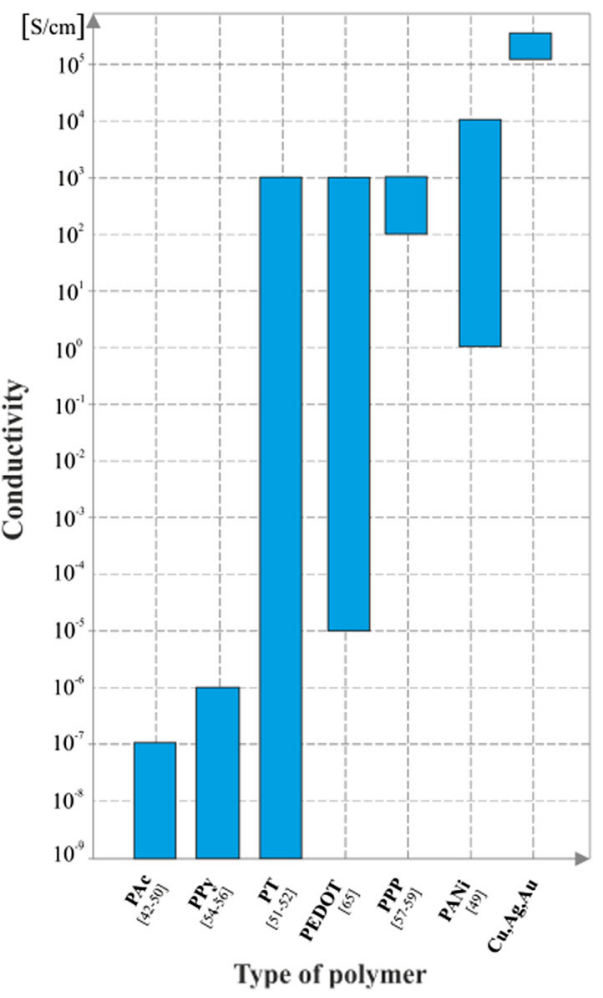

Figure 1 Comparison of the electric conductivity range of conductive polymers and metals $(\mathrm{Cu}, \mathrm{Au}, \mathrm{Ag})$, data taken from [42-59], [65].

filler, which is PPS, resulted in thicker metallic layers and the inclusion of copper grains in the polymer matrix, due to which a new polymer composite with very good adhesive properties of the metallic layer was obtained. This thread of research should be deepened by using other fillers in combination with PPy. Research by Nichols et al. [72] showed that PPy metallization is more effective at defective sites, e.g., the edges of polymer electrodes. This may be due to the increased current density flowing through the irregular fragments of the polymer. Therefore, it can be concluded from this experience that the mechanical treatment of the polymer electrode surface, for example, grinding, sandblasting or laser ablation, can contribute to the local increase in the current density on the electrode surface, and the coating process will have fasted and more efficient.

\section{Conductive polymer composites and applied fillers}

Thermoplastic polymer composites are particularly important in high-volume production. They are a very good alternative to conventional construction materials such as steel, aluminum, or titanium. Relatively simple processing reduces the price of the product and the amount of waste. In addition to the low price, thermoplastic composites have the following advantages: low specific weight, capacity to damp vibrations, ease of product shaping, resistance to corrosion, and high fatigue strength. The disadvantages, however, are low-temperature resistance, strength, and stiffness as compared to the properties of conventional construction materials [74].

\section{Conductive fillers}

Using the electrodeposition method is generally not possible for thermoplastic polymers. It results from the electrical insulation of the polymer material. On the other hand, it is possible to compound polymer material with conductive fillers to increase conductivity. The most commonly used conductive fillers are metal particles, metal fibers, carbon black, graphite, graphene, carbon nanotubes, and carbon fibers. The electrical conductivity of that composites depends mainly on the volume fraction of the conductive filler and its electrical conductivity. Small particles of the filler result in large distances between their centers, which means that the conductivity of the entire composite is limited to the electrical conductivity of the polymer matrix (depending on the choice of matrix material) [75]. Increasing the number of filler particles reduces the distances between the centers of these particles until a certain critical value is reached, at which an abrupt increase in electrical conductivity is reached. This critical value is called the percolation threshold-the percentage of filler above which continuous conductive areas are formed in the composite matrix. The electrical conductivity can vary by several orders of magnitude for small differences in the filler content. Only when its content is sufficiently large, numerous conducting areas form a three-dimensional network. Then, a further increase in the volume of the filler does not cause significant changes in conductivity. In this review, the aspects related to percolation issues were omitted, on which a detailed discussion can be found elsewhere [76-79]. 
Figure 2 summarizes the most commonly used fillers. It shows the levels of electrical conductivity and the size of the particles added to the polymer matrices. The bar graph also includes references to specialist literature for more detailed information.

Figure $2 b$ shows the size ranges of the filler particles. The lower value of each bar corresponds to the minimum value of the particle size, and similarly, the higher value of the bar corresponds to the maximum value of the filler particle. In the case of graphene and graphite, it is difficult to talk about the particle size, hence the concept of distances between adjacent atoms in one layer and $\left(^{*}\right)$ and distance between layers (**) was introduced. Similarly, with CNT and AgNWs - the particle length can be determined-it is shown as the higher value on the bar, while the lower value on the bar corresponds to the tube/wire diameter value( $\left.{ }^{* * *}\right)$. These special cases are marked with markers in the graph.

It is worth paying special attention to graphene and nanotubes. The addition of these fillers to the polymer matrices significantly changes the electrical properties of the polymer composite. Graphene has a high electrical conductivity of up to $10^{8} \mathrm{~S} / \mathrm{cm}$ and allows for high current densities of $10^{8} \mathrm{~A} / \mathrm{cm}^{2}$, which is several times more than in the case of metallic conductors. This is a very important feature that can affect the performance and rate of the metallization process of a polymer composite. Nanotubes are also used as fillers. Single-walled nanotubes (SWCNT) have conductive and semiconductor properties, while multi-walled nanotubes (MWCNT) have conductive properties. When selecting the filler, it is worth paying attention to the particle size. Fillers should be used with different scales: millimeters, micrometers, and nanometers. This will create conductive paths inside the polymer. Also, note the aspect ratio of the filler particles. The high value of the aspect ratio is responsible for a significant reduction in the percolation threshold of the polymer composite. This allows electroplating at lower filler percentages.

\section{The electrical conductivity of selected conductive composites.}

Polylactide (PLA) with the addition of carbon nanotubes (MWCNT) or carbon black (CB) were investigated [101]. The fillers were dispersed and mixed in the polymer solution subjected to ultrasound treatment. The polymer-solvent was ethylene chloride or chloroform, which showed good nanotubes dispersion. The solvent was then removed by filtration and drying at about $60{ }^{\circ} \mathrm{C}$ (for $6 \mathrm{~h}$ ) to prevent the aggregation of the filler particles. The samples were then pressed at a temperature of about $180{ }^{\circ} \mathrm{C}$. Their electrical conductivity was greater than $10^{-6} \mathrm{~S} / \mathrm{m}$. The measurement was made using the four-probe electrode methods. The percolation threshold for the composite using nanotubes was $0.25 \mathrm{wt} . \%$, while for CB it was $2.48 \mathrm{wt}$.\%. The electric conductivity value for the composite containing CNT was 100 times higher than for that containing CB and was $5 \bullet 10^{-2} \mathrm{~S}$ / $\mathrm{cm}$. The cause of this difference can be the aspect ratio, which is over 1000 for CNT as compared to CB.

Composites with polymer matrices of low-density polyethylene (PE-LD), polypropylene (PP), and polystyrene (PS) as well as CB as a filler were also investigated [106]. Toluene, benzene, and xylene were used as solvents. Composites were obtained from concentrates containing $20 \mathrm{wt} . \%$ of the filler. The components of the composite were mixed in a chamber at a speed of $60 \mathrm{rpm}$ and a temperature of about $190{ }^{\circ} \mathrm{C}$. Samples for electrical tests were produced by the hot-pressing method. It was found that percolation thresholds were $2 \mathrm{wt} . \%$ for PS, $2 \mathrm{wt}$.\% for PP, and $4 \mathrm{wt} . \%$ for PE-LD. It was also observed that the formation of conductive paths of the filler in the matrix was influenced by the type of polymer as well as its degree of crystallinity. After exceeding the percolation threshold, the conductivity of PP and PS was of the order $1 \bullet 10^{-5} \mathrm{~S} / \mathrm{m}$, while for PE-LD this value was about $2 \bullet 10^{-4} \mathrm{~S} / \mathrm{m}$ [106].

The electrical conductivity of graphene-reinforced composites based on polyvinyl chloride (PVC) or polymethyl methacrylate (PMMA) matrix was determined [107]. The conductive network of graphene particles was formed at about $5 \mathrm{wt} . \%$. it's content in the PMMA matrix and about $10 \mathrm{wt} . \%$. in PVC. The maximum electrical conductivity of about $4 \bullet 10^{-4} \mathrm{~S} / \mathrm{cm}$ was achieved at $20 \mathrm{wt}$.\%. graphene content. The PVC/graphene composite has a relatively higher conductivity than that obtained with the use of the PMMA matrix. This may indicate a better dispersion of graphene particles in the PVC matrix.

The properties of polymer composites containing silver particles were examined [75]. The matrixes used were polyamide (PA6) and polytetrafluoroethylene (PTFE) in the form of powders with particle sizes from about 40 to about $80 \mu \mathrm{m}$, while $\mathrm{Ag}$ 
particles were smaller than $20 \mu \mathrm{m}$. The composite was prepared by mixing the powders in a high-speed mill and then hot sintered at a temperature of $200{ }^{\circ} \mathrm{C}$ - for PA6 and $400{ }^{\circ} \mathrm{C}$ for PTFE. In the tests, the filler content was about $30 \mathrm{wt} . \%$. The test results showed that the electrical conductivity of the obtained composites ranged from $28 \cdot 10^{-3} \mathrm{~S} / \mathrm{cm}$ to $5 \mathrm{~S} / \mathrm{cm}$.

The properties of polymer composites using metal fibers were also investigated. Bigg et al presented a composite with a polypropylene (PP) or polyester resin matrix using aluminum fibers with a high aspect ratio as a filler [108]. The conductivity of the composite below $50 \bullet 10^{-3} \mathrm{~S} / \mathrm{cm}$ was obtained, by adding randomly dispersed aluminum fibers with different lengths and diameters.

Polypropylene (PP) with fillers was rolled at a temperature of $200{ }^{\circ} \mathrm{C}$ [109]. There is a minimum gap in the rolling machine of $3 \mathrm{~mm}$ to keep the aluminum fibers from breaking during mixing. On the other hand, PE composites were mixed and solidified at a temperature of $80{ }^{\circ} \mathrm{C}$. The percolation threshold was obtained for the composite with the use of fibers $3.05 \mathrm{~mm}$ long, $0.127 \mathrm{~mm}$ in diameter, and with an aspect ratio of 24.0 at the content of $6 \mathrm{vol} . \%$, while for the composite, where the fibers were $1.25 \mathrm{~mm}$ long, $0.1 \mathrm{~mm}$ in diameter and aspect ratio 12.5, the threshold was 11 vol.\%. Above the percolation threshold, the resistivity of the composite did not change significantly. Based on the observations, the influence of the aspect ratio on the resistivity of the samples was determined. The use of fibers with a length of $3.05 \mathrm{~mm}$, a diameter of $0.127 \mathrm{~mm}$, and an aspect ratio of 24.0 at a content of 7.7 vol.\% resulted in conductivity of $80 \bullet 10^{-3} \mathrm{~S} / \mathrm{cm}$ [108].

Researchers from the University of Tokyo examined a composite with an ABS matrix using copper fiber as a filler and a solder filler [110]. The components of the composite were mixed and kneaded at a temperature of $210{ }^{\circ} \mathrm{C}$ for $10 \mathrm{~min}$. The copper fibers were $6 \mathrm{~mm}$ long and $50 \mu \mathrm{m}$ in diameter. The test specimens were pressed into a mold at a temperature of $160-180{ }^{\circ} \mathrm{C}$ under the pressure of $100 \mathrm{MPa}$ and $200 \mathrm{MPa}$. The problem with the fluidity of the composite material was noticed-the mold was not filled. It resulted probably from the contact and entanglement of the filler fibers. The tests showed that the volume resistivity of samples increases significantly when kneading takes place in atmospheric conditions, which is probably caused by the oxidation of copper fibers. The obtained values of the volume conductivity are $5 \bullet 10^{3} \mathrm{~S} / \mathrm{cm} \quad(16.2 \% \quad$ vol. $)$; $10.75 \bullet 10^{3} \mathrm{~S} / \mathrm{cm}$ (vol. $30 \%$ ), and $16.67 \bullet 10^{3} \mathrm{~S} / \mathrm{cm}$ (vol. 40\%) [110]. The measurements were made using the four-probe method. The electrical contact was made by soldering the wire to the drilled sample. The dependence of changes in resistivity as a function of temperature was also investigated. For this purpose, a current of $10 \mathrm{~A}$ was applied to the sample, and resistivity was measured as dependent on temperature changes. The significant change took place only for the sample with dimensions of $3 \times 3 \times 90 \mathrm{~mm}$. The reason for this was probably the low filler content $(16.2 \%$ vol.). The metallic connections formed by the filler particles had a smaller cross section for a sample with dimensions of $3 \times 3 \times 90 \mathrm{~mm}$ than $5 \times 6 \times 90 \mathrm{~mm}$ [110]. Forcing a current of $10 \mathrm{~A}$ to flow with a smaller cross-section of the conductive paths resulting in an increase in temperature according to the Joule's-Lenz law. On the other hand, the increase in temperature caused a further increase in resistance, along with according to the dependence of the conductor resistance on temperature, expressed as follows:

$R_{T}=R_{0} \cdot\left[1+\alpha \cdot\left(T-T_{0}\right)\right]$

$R_{0}$-conductor resistance at temperature $20{ }^{\circ} \mathrm{C}, R_{\mathrm{T}}-$ resistance of a conductor heated to temperature $T, \alpha-$ temperature coefficient of resistance, which for copper, aluminum, and silver is $0,0041 /{ }^{\circ} \mathrm{C}$.

A continuation of Bigg's and Naguchi's research was the hybrid composite with very high electrical conductivity developed by Michaeli et al. [111]. The obtained material consisted of 15 wt.\% of PA6 polymer, 33\% wt of a tin/zinc alloy with a melting point of $199{ }^{\circ} \mathrm{C}$, and 52 wt.\% copper fibers. The total filler content was about $85 \mathrm{wt} . \%$, which is about $44 \mathrm{vol} \%$. The copper fibers used were $0.65 \mathrm{~mm}$ long and $35 \mu \mathrm{m}$ in diameter. The test samples were made by the injection method. The electrical conductivity was of the order $10^{4} \mathrm{~S} / \mathrm{m}$. The tests showed a slight dependence of the resistivity on the temperature when heated to the glass transition temperature which is 50-60 ${ }^{\circ} \mathrm{C}$ for PA6. A decrease in conductivity was noted after exceeding the temperature of $170{ }^{\circ} \mathrm{C}$. The thermoplastic composite, highly filled with metallic particles, also showed changes in its mechanical properties. The flexibility of the composite decreased significantly compared to the starting material-PA6. 

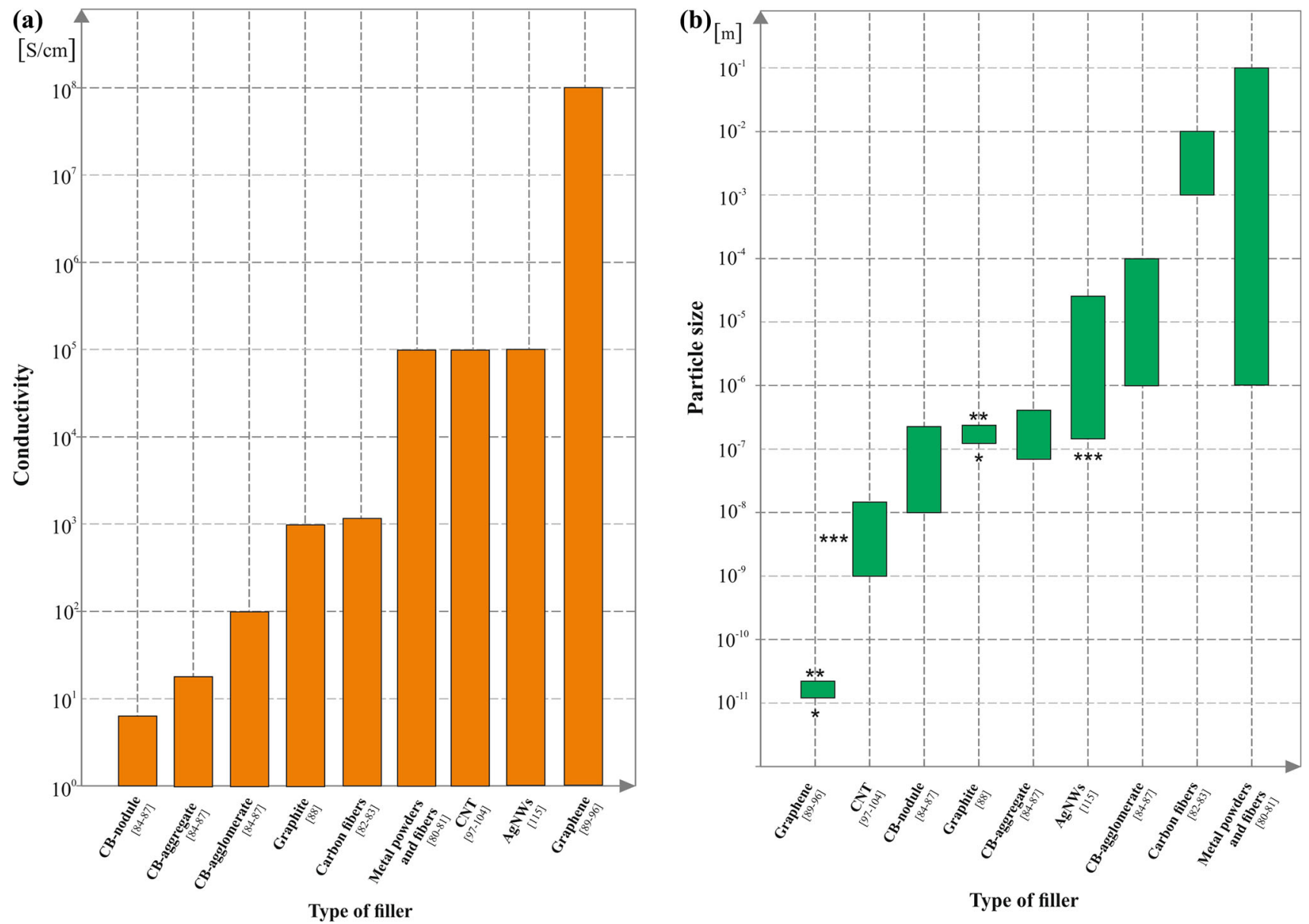

Figure 2 Selected conductive fillers: a comparison of the conductivity, b comparison of the particle size, data taken from [80-104], [105].

Some problems have also arisen with the proper filling of the injection mold [111].

In the work of Flowers et al. [112], commercially available conductive filaments for $3 \mathrm{D}$ printing were tested. Thermoplastics with conductive fillers such as Electrifi, Black Magic (PLA + graphene), and ProtoPasta (PLA + CB) were tested. An inexpensive (less than \$1000) open-source dual-material 3D printer was used for the experiment. A resistor, inductor, and capacitor were successfully built and their impedances were measured. The conductivity of the printed samples was measured: for Proto-Pasta it was $8.33 \cdot 10^{-2} \mathrm{~S} / \mathrm{cm}$, for Black Magic $1.28 \mathrm{~S} / \mathrm{cm}$, and Electrifi $71.4 \mathrm{~S} / \mathrm{cm}$ [112]. The Source Meter-Keithley 2400 was used to measure the conductivity. Due to these values, these materials find practical application in the construction of electronic passive elements, such as resistors, coils, and capacitors. The highest value of conductivity was shown by Electrifi, which can effectively enable electroplating.
Mechanical properties of the tested materials were observed. The samples from Black Magic and ProtoPasta, due to the high content of carbon black and graphene, showed high brittleness and cracked. By contrast, Electrifi (containing copper particles) could be knocked down at least 500 times with a slight change in resistance.

The research results presented in this section show that there is a real problem with the change of electrical conductivity of a polymer material sufficient for direct electroplating. Figure 3 presents comparative electrical conductivity values for the tested composites.

The highest conductivities were obtained when metal fibers were used as fillers. The expected result is due to the conductivity of the filler. The conductivities obtained for this type of filler (metal fibers) approached the value of the electric conductivity of the metal but were lower by two orders of magnitude. It can be assumed with high probability that 
such good results are dependent on the size of the filler and the aspect ratio of a single conductive particle. The obtained values of electrical conductivity suggest that the electroplating process of such a conductive composite will be efficient and fast. Satisfactory results from the point of view of electroplating were obtained for metal powders. These composites showed lower conductivity than with the use of metal fibers, but high enough to assume with a high probability that the electroplating process will be effective. The worst values of electrical conductivity concerned polymer composites using CB. This was not due to the low conductivity of the filler itself, but rather the distance between the conductive particles arranged in the matrix. In this case, the probability of creating a continuous conductive path inside the matrix is much lower than with metal fibers or nanotubes.

\section{Electroplating of conductive polymer composites}

The hybrid composite called Schulatec TinCo 50 was tested by the Hansen team, the results of which are presented in [114]. The composite sample was the cathode, while the anode was pure copper. The electroplating bath was a solution of sulfuric acid and copper sulfate. The experiments were repeated for different values of the metallization time and current density. Increasing the current density from 3 to $8 \mathrm{~A} /$ $\mathrm{dm}^{2}$ along with extending the processing time from 6 to $11 \mathrm{~min}$ resulted only in $12 \%$ coverage of the sample surface. The causes of such poor electroplating were also investigated. The sample was subjected to microscopic observation. Morphology analysis showed that only $7 \%$ of the composite surface had exposed copper fibers. On the other hand, the visible areas of $\mathrm{Cu}$ fibers were covered with a thin layer of polymer material. The level of adhesion was determined to be weak. The surface was mechanically treated by sandblasting and wet grinding. Due to these treatments, the surface of the sample had about $17 \%$ metallic coverage, which enabled electroplating of about $45 \%$ of the sample surface. The electrical conductivity of the samples subjected to electroplating was also tested. Even the incompletely covered sample ( $45 \%$ of the area) showed an increase in conductivity by about $70 \%$. After the mechanical treatment, the deposited metallic layer was subjected to a tape test-it was not possible to remove the metal with the tape [114].

The paper [115] presents the research on the dependence on the effectiveness of electroplating on polymer 3D printed products. Conductive filaments available on the market, intended for 3D printing, such as Electrifi, Black Magic, and Proto-Pasta, were used for the tests. On acrylic substrates, samples for testing with sizes $0.1 \times 0.5 \times 8 \mathrm{~cm}$ were made. Copper electrodeposition was carried out in a twoelectrode system, where the working electrode was a sample printed from a conductive filament, and the counter electrode was copper foil. The area of electroplating deposition was $4.25 \mathrm{~cm}^{2}$. The electrolyte, an aqueous solution of $\mathrm{CuSO}_{4}(1.0 \mathrm{M}), \mathrm{H}_{2} \mathrm{SO}_{4}(0.5 \mathrm{M})$, and $\mathrm{NaCl}(1 \mathrm{mM})$ was used for the metallization bath. A DC source was used for electrolysis and the metallization current density was $50 \mathrm{~mA} / \mathrm{cm}^{2}$. The calculated value of the copper deposition rate was $1.1 \mu \mathrm{m} / \mathrm{min}$ (with full current efficiency-50 mA/ $\mathrm{cm}^{2}$ ). The research showed that the process of copper electrodeposition runs unevenly on the printed sample surface. A higher potential was near the electrical contact, which decreased along from this contact. This resulted in the deposition of less copper in the areas remote from the electrical contact. A sample made of commercial Proto-Paste was covered with a continuous layer of copper only $2 \mathrm{~cm}$ from the electrical contact, after one hour of electroplating. The high filament resistance caused the current density to drop below $3 \mathrm{~mA} / \mathrm{cm}^{2}$. Hence, the deposition of copper particles took place near the electrode contact.

The electroplating of the sample made of Black Magic showed after $5 \mathrm{~min}$ the formation of a metallic layer near the electrical contact. However, after one hour of the experiment, full coverage of the sample was obtained. The microscopic measurements showed inhomogeneity of the copper layer, which was also confirmed by the resistivity measurements. Surface resistivity increased with increasing distance from electrode contact. The resistance between 0 and $1.5 \mathrm{~cm}$ is nearly 7 times lower than that between 4.5 and $6 \mathrm{~cm}$.

The electroplating of copper on a sample made of Electrifi resulted in a homogeneous metallic layer as initially proved by visual examination. On the other hand, surface images taken with an optical and electron microscope showed heterogeneity of the layer. Within $5 \mathrm{~min}$, the deposition took place only around the electrical contact. After $15 \mathrm{~min}$, larger 
areas of the sample were covered. In contrast, after $30 \mathrm{~min}$ of electroplating, the almost entire surface of the sample was covered with a metallic layer having locally present voids. Finally, after one hour of the process, the entire surface of the sample was covered with copper. The SEM images revealed that the copper deposition exhibited relatively high roughness and porosity. There have been no studies on the adhesion of the metallic layer to the substrate.

The work of Angel et al. presents the results of research on the electroplating deposition of details created thanks to 3D printing with the use of a twohead printer [116]. During the simultaneous operation of the 3D-printing process, one of the two heads fed non-conductive PLA filament, and the other conductive filament-Proto-paste. The samples were printed in two different directions: parallel to the work surface (" $x-y$ " direction) and perpendicular to it (" $z$ " direction). The conductivity of the product was tested with a multimeter in both directions: " $x-y$ " direction $-81.9 \cdot 10^{-3} \mathrm{~S} / \mathrm{cm}$ and " $\mathrm{z}$ " direction -
$43.310^{-3} \mathrm{~S} / \mathrm{cm}$. An aqueous solution of copper sulfate was used for electroplating. The working electrode was an area printed from a conductive material, while the counter electrode was a copper foil placed in the bath parallel to the coated surface. The current source was a switching power supply, forcing a current flow of $0.04 \mathrm{~A}$ which corresponded to a current density of about $2 \mathrm{~mA} / \mathrm{mm}^{2}$. The electroplating deposition process for the tested samples lasted 2, 4, 6 , and $8 \mathrm{~h}$. The deposition thickness of the metallic layer was determined using a confocal laser microscope. The metal layer deposition rates were obtained for the sample printed in the " $x-y$ " direction at the rate of $24 \mu \mathrm{m} / \mathrm{h}$ and for the sample printed in the " $\mathrm{z}$ " direction-at the rate of $17 \mu \mathrm{m} / \mathrm{h}$.

Images of the metallic layer morphology were taken using computed tomography (Zeiss Xradia 510 Versa CT scanner) for the samples subjected to electroplating for $8 \mathrm{~h}$. Numerous cracks can be seen in the copper layer, especially in the sample printed in the " $x-y$ " direction. The thickness of the deposited

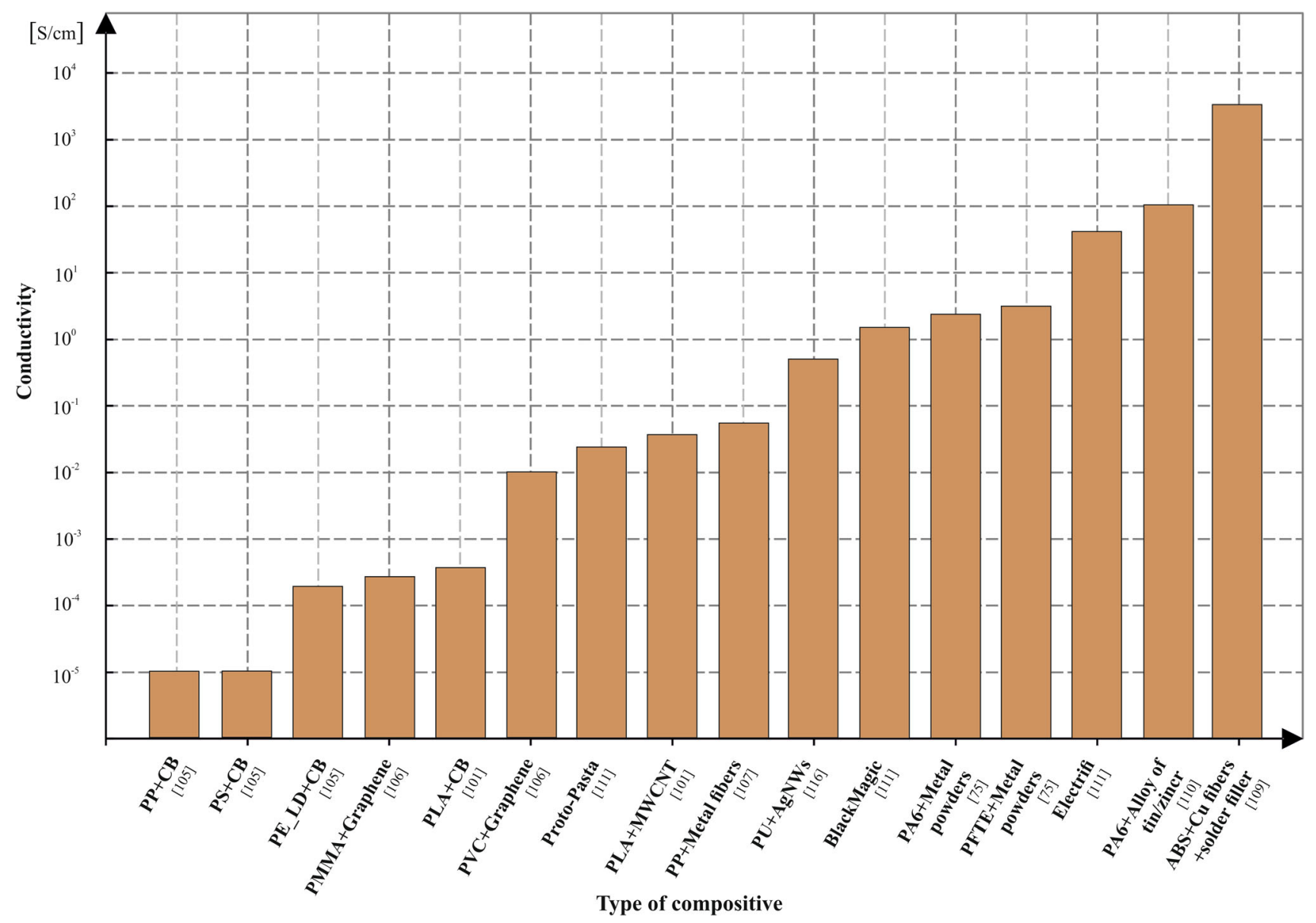

Figure 3 Comparison of obtained electrical conductivities of conductive composites, data taken from [75], [101], [105-111], [112], [113]. 
copper layer differed depending on the sample printing direction, and so for the " $x-y$ " direction the layer had a thickness from 130 to $420 \mu \mathrm{m}$, and for the " $\mathrm{z}$ " direction this thickness was from 230 to $620 \mu \mathrm{m}$. The metallic layers on the conductive Proto-Paste filament, obtained in the process of electroplating had considerable roughness, different thicknesses, and discontinuities. The adhesion test according to the ASTM D3359 standard [105] was performed. The results showed that the adhesion of the obtained metallic layer to the substrate was rated $4 \mathrm{~A}-$ "Trace peeling or removal along incisions or at their intersection" [116].

In the work of Dupenne et al. [113], the preparation of a polymer composite consisting of a polyurethane matrix (PU) and silver nanowires (AgNWs) was reported. AgNWs were synthesized by reducing $\mathrm{AgNO}_{3}$ with ethylene glycol in the presence of poly(vinylpyrrolidone). The detailed course of the process was included in [117]. The conductivity of a single silver nanowire tested at room temperature was $6.3 \bullet 10^{5} \mathrm{~S} / \mathrm{cm}$ [113]. Previously, the issue was dealt with by Sun et al. [118]. The use of AgNWs instead of spherical silver particles significantly lowered the percolation threshold (from 20\% vol. to less than $5 \%$ vol.). The reason for this was the high aspect ratio of 222. With such a low filler content, it was possible to maintain the mechanical properties and low weight compared to spherical silver particles $[113,117]$. The conductivity of undoped PU is $10^{-12} \mathrm{~S} / \mathrm{cm}$. However, at $4 \%$ vol. filler content, the conductivity of the composite was $6.8 \bullet 10^{-1} \mathrm{~S} / \mathrm{cm}$. The measurements were performed using the fourpoint method [113]. A percolation threshold of $0.6 \%$ vol. of the filler content was noted. Above the percolation threshold, effective electroplating of the composite was noted. The electrolysis process uses a silver electrode as the anode and a composite as the cathode. Electroplating was applied to PU composite samples with a content of $3 \%$ vol. to $6 \%$ vol. AgNWs. No effect of the degree of filler content on the metallization efficiency was observed. In this process, the duration of the electrolysis process and the current density were of decisive importance. The optimal conditions for electroplating were obtained with the share of $4 \%$ vol. filler and for a current density of $0.1 \mathrm{~A} / \mathrm{dm} 2$. The deposition rate was recorded at the level of $7 \mu \mathrm{m} / \mathrm{h}$ [113]. The adhesion of the metallic layer to the polymer composite substrate was also determined using the ISO 2409 standard. The dependence of the adhesion on the current density of the electrolysis process was observed. For a density value lower than $0.2 \mathrm{~A} / \mathrm{dm} 2$, the metal layer had the adhesion class 0 -perfect adhesion. Increasing the value of the current density caused the deterioration of the adhesive properties of the metallic layer to the substrate.

The paper by Li et al. [119] presents the results of research on a composite consisting of a conductive polymer-polythiophene and nickel nanoparticles (NiNPs). PT was obtained by polymerizing thiophene monomers on FR4 substrate with $\mathrm{KMnO}_{4}$. NiNPs particles were introduced into the polymer matrix using a proprietary method, not described in detail in the article. Two samples were prepared: one with NiNPs in the PT matrix and the other with undoped PT. Both samples were placed in a copper plating solution where the samples were the cathode and the copper electrodes were the anode. The experiment was carried out at a current density of $3.75 \mathrm{~A} / \mathrm{dm} 2$. A detailed description of the process and rocks of the galvanic bath is given in [119]. After $30 \mathrm{~min}$ of the experiment, massive nuclei of copper particles appeared, while after an hour of electrolysis, complete coverage of the sample with a metallic layer was observed. The deposition rate of the copper layer on the PT + NiNPs composite was measured and it was $14.55 \mu \mathrm{m} / \mathrm{h}$ [119]. Such a rapid increase in copper layer deposition was initiated by the presence of NiNPs particles. The tests also showed that the sample without NiNPs particles was not covered with the copper layer. The thesis was formulated that NiNPs must be present in the PT matrix for the electroplating process to take place. Adhesion tests according to ISO 2409-1992 were also performed. The test results showed no damage to the metallic layer, which can be classified as class 0 -excellent adhesion. There were also made PT + NiNPs tracks on the FR4 substrate, which were subjected to electroplating. As a result, conductive tracks with a resistance of $0.35 \Omega$ were obtained, which powered the LED [119].

The conducted tests of conductive composites commercially available on the market in terms of the effectiveness of electroplating are presented in this section of the paper. It can be seen that in almost each of the cited examples there was a problem with the metallization of the polymer composite. The electroplating had possible for materials such as Schulatec TinCo 50, Proto-Pasta, or Black Magic. Unfortunately, it was not effective. The obtained metallic layer was 
not continuous and was present mainly in the vicinity of the electrical contact and the polymer electrode. Even mechanical processing-surface grinding (for TinCo 50) improved the metallization result up to $45 \%$ of the sample surface. The results of tests of filaments commonly used in 3D printers also gave a similar result. A higher electric potential could be observed near the electrode-polymer composite interface. Near this place, the deposition of the metallic layer was successful, but it disappeared with the increase of distance from the point of electrical contact. Similar problems occurred with the electroplating of conductive polymers (Sect. 3.2). The lack of uniform deposition of the metallic layer on the entire surface of the sample resulted in an extension of the experiment time. The obtained layers showed a different thickness and roughness. Only the use of silver nanowires as a filler significantly lowered the percolation threshold in the PU matrix. This enabled the electroplating process to be successfully carried out. The obtained metallic layer showed very good adhesion and smoothness. Similarly, doping the conductive polymer (PT) with nickel nanoparticles created a composite that can be efficiently and quickly electroplated.

\section{Conclusions}

Conventional polymers are typically insulators and their electroplating requires inducing changes in their composition and structure by chemical or physical methods. These indirect methods are part of the electroplating process and require multiple steps. Agents used to activate, oxidize, and etch the surface of polymers are highly polluting and pose a threat to human health. From the economic point of view, chemical and physical methods involve highly specialized equipment, which contributes to the final price of the product.

The main problem of implementing the method of electroplating of conductive composites is, above all, the ineffectiveness of the process. It is caused by the still too low electrical conductivity of polymers and polymer composite and the dependence of the electrical potential which decreases too high with increasing from the electrical contacting point. Research should be carried out on obtaining a higher electrical conductivity of the polymer composite as well as a uniform potential distribution on the surface of the metalized sample. The search should be aimed at finding the optimal filler content of various fractions on the scale of nanometers, micrometers, and millimeters, so that the composite has the mechanical properties of the polymer material. This is important due to the possible industrial processing of the product (e.g., 3D printing or injection molding). Only solving these problems will enable the implementation of the method on an industrial scale. Therefore, this technology needs further development and research with new total concepts which will be presented in our next successive publications.

\section{Declaration}

Conflict of interest The authors declare that they are not affiliated with any organization or anyone who has a direct financial contribution to the subject of research or materials studied in a given work (e.g., employment, consulting, shareholding, fees).

Open Access This article is licensed under a Creative Commons Attribution 4.0 International License, which permits use, sharing, adaptation, distribution and reproduction in any medium or format, as long as you give appropriate credit to the original author(s) and the source, provide a link to the Creative Commons licence, and indicate if changes were made. The images or other third party material in this article are included in the article's Creative Commons licence, unless indicated otherwise in a credit line to the material. If material is not included in the article's Creative Commons licence and your intended use is not permitted by statutory regulation or exceeds the permitted use, you will need to obtain permission directly from the copyright holder. To view a copy of this licence, visit http://creativecommons.org/licen ses/by $/ 4.0 /$.

\section{References}

[1] Żak T (2002) Poradnik Galwanotechnika 4th ed. WNT, Warszawa

[2] Mehdizadeh M, Khorasanian M, Baghal S (2018) Direct electroplating of nickel on ABS plastic using polyaniline silver surface composite synthesized using different acids. J Coat Technol Res. https://doi.org/10.1007/s11998-018-0 $075-2$ 
[3] Guo RH, Jiang SQ, Yuen CWM, Ng MCF (2009) An alternative process for electroless copper plating on polyester fabric. J Mater Sci Mater Electron 20:33-38

[4] Li D, Goodwin K, Yang C (2008) Electroless copper deposition on aluminum-seeded ABS plastics. J Mater Sci 43:7121-7131. https://doi.org/10.1007/s10853-008-3031-1

[5] Domenech SC Jr, Lima E, Drago V, De Lima JC, Borges Jr NG, Avila AOV, Soldi V (2003) Electroless plating of nickel-phosphorous on surface-modified poly(ethylene terephthalate) films. Appl Surf Sci 220:238-250

[6] Celozzi S, Araneo R, Lovat G (2008) Electromagnetic shielding. Wiley Inc, Hoboken

[7] Gryz K, Karpowicz J, Kurczewska A, Stefko A (2009) Ograniczenie ryzyka zawodowego przy źródłach pól elektromagnetycznych-przegląd wybranych materiałów barierowych. Bezpieczeństwo Pracy 3:22-26

[8] Indulski IA (1987) Kryteria zdrowotne środowiska. Fale radiowe i mikrofale, PZWL, Warszawa

[9] Unnikrishnan D (2006) Potentiel de la technologie MID pour les composants passifs et des antennes, PhD Dissertation, Universite De Grenoble

[10] Franke J (2014) Three-dimensional molded interconnect devices (3D-MID). Hanser, Monachium

[11] Franke J (1995) Integrierte Entwicklung neuer Produktund Produktionstechnologien für räumliche spritzgegossene Schaltungsträger(3-D MID), Dissertation, Erlangen

[12] Mai TT, Schultze JW, Staikov G (2004) Relation between surface preconditioning and metal deposition in direct galvanic metallization of insulating surfaces. J Solid State Electrochem 8:201-208

[13] Mai TT, Schultze JW, Staikov G, Munoz AG (2005) Mechanism of galvanic metallization of $\mathrm{CoS}$-activated insulating polymer surfaces. Thin Solid Films 488:321-328

[14] Pan CT (2004) Selective electroless copper plating microcoil assisted by $248 \mathrm{~nm}$ excimer laser. Microelectr Eng 71:242-251

[15] Carraro C, Maboudian R, Magagnin L (2007) Metallization and nanostructuring of semiconductor surfaces by galvanic displacement processes. Surf Sci Rep 62:499-525

[16] Hari KK, John S, Srinivasan KN, Praveen J, Ganesan M, Kavimani PM (2006) An overall aspect of electroless Ni-P deposition-A review article. Metal Mater Trans 37A:1917-1926

[17] Hryniewicz T (2004) Technologia powierzchni i powłok. Wydawnictwo Politechniki Koszalińskiej, Koszalin

[18] Kotnarowska D (2007) Powłoki ochronne. Wydawnictwo Politechniki Radomskiej, Radom

[19] Charbonnier M, Romand M, Goepfert Y, Leonard D, Bouadi M (2006) Copper metallization of polymers by a palladium-free electroless process. Surf Coat Technol 200(18-19):5478-5486

[20] Mallory GO (2002) Electroless plating: fundaments and applications. Noyes Publications/William Andrew Publications, New York

[21] Touir R, Larhzil H, Ebntouhami M, Cherkaoui M, Chassaing E (2006) Electroless deposition of copper in acidic solutions using hypophospite reducing agent. J Appl Electrochem 36:69-75

[22] Burke LD, Bruton GM, Collins JA (1998) The redox properties of active sites and the importance of the latter in electrocatalysis at copper in base. Electrochim Acta 44:1467-1479

[23] Charbonnier M, Romand M (2003) Polymer pretreatments for enhanced adhesion of metals deposited by the electroless process. Inter J Adhesion Adhesives 23:277-285

[24] Mattox DM (1998) Handbook of physical vapor deposition (PVD) Processing 2nd ed. Noyes Publication, Westwood

[25] Malandrino G, Jones AC, Hitchman ML (2009) Chemical vapor deposition. precursors, processes and applications. Angew Chem 121(41):7614-7615. https://doi.org/10.1002 /ange.200903570

[26] Sung Y, Chou YH, Hwu WH, Fan YC, Cheng JL, Ger MD (2009) Electroless copper deposition by non-isothermal deposition technology. Mat Chem Phys 113:303-308

[27] Lee C, Huang Y, Kuo L (2007) Catalytic effect of Pd nanoparticles on electroless copper deposition. J Solid State Electrochem 11:639-646

[28] Mubarak A, Hamzah E, Toff MRM (2005) Review of physical vapour deposition (PVD) techniques for hard coating. J Mekanikal 20:42-51

[29] Forster J, Gopalraja P, Gung TJ, Sundarrajan A, Fu X, Hammond N, Fu J, Kelkar U, Bhatnagar A (2005) A PVD based barrier technology for the $45 \mathrm{~nm}$ mode. Microelectr Eng 82:594-599

[30] Grigorov GI, Grigorov KG, Sporken R, Caudano R (1996) Ion - induced densification of PVD films-a choice of the optimum density of ion bombardment. Appl Phys A 63:399-401

[31] Burakowski T, Wierzchoń T (1995) Inżynieria powierzchni metali. WNT, Warszawa

[32] Dobrzański LA (2009) Kształtowanie struktury i właściwości powierzchni materiałów inżynierskich i biomedycznych. International OCSCO World Press, Gliwice

[33] Michalski AJ (2000) Fizykochemiczne podstawy otrzymywania powłok z fazy gazowej. Oficyna Wydawnicza Politechniki Warszawskiej, Warszawa

[34] Doppelt P (1997) Copper CVD precursors and processes for advanced metallization. Microelectr Eng 37(38):89-95 
[35] Devi A, Shivashankar SA (1998) Thermal chemical vapour deposition of copper films from copper ethylacetoacetate: microstructure and electrical resistivity. J Mater Sci Lett 17:367-369. https://doi.org/10.1023/A:1006518714011

[36] Norman JAT, Perez M, Schultz SE, Waechtler T (2008) New precursors for CVD copper metallization. Microelectr Eng 85:2159-2163

[37] Kada T, Ishikawa M, Machida H, Ogura A, Ohshita Y, Soai K (2005) Volatile CVD precursors for Ni film: cyclopentadienylallynickel. J Crystal Growth 275:e1115-e1119

[38] Minczewski J, Marczenko Z (2020) Chemia analityczna, PWN, Warszawa, vol. 1, 2

[39] Jones L, Atkins P (2019) Chemia ogólna-cząsteczki, materia, reakcje. PWN, Warszawa

[40] Nezakati T, Seifalian A, Tan A, Seifalian AM (2018) Conductive Polymers: opportunities and challenges in biomedical applications. Chem Rev 118(14):6766-6843. h ttps://doi.org/10.1021/acs.chemrev.6b00275

[41] Kumar D, Sharma RC (1998) Advances in conductive polymers. Eur Polymer J 34(8):1053-1060

[42] Lam JWY, Tang BZ (2005) Functional polyacetylenes. Acc Chem Res 38:745-754

[43] Rosen BM, Wilson CJ, Wilson DA, Peterca M, Imam MR, Percec V (2009) Dendron-mediated self-assembly, disassembly, and self-organization of complex systems. Chem Rev 109:6275-6540

[44] Yashima E, Maeda K, Iida H, Furusho Y, Nagai K (2009) Helical polymers: synthesis, structures, and functions. Chem Rev 109:6102-6211

[45] Mao Y, Xu HP, Zhao H, Yuan WZ, Qin A, Yu Y, Faisal M, Xiao AZ, Sun JZ, Tang BZ (2011) Composites of quaternized poly(pyridylacetylene) and silver nanoparticles: nanocomposite preparation, conductivity, and photoinduced patterning. J Mater Chem 21:13627-13633

[46] Masuda T, Higashimura T (1984) Synthesis of high polymers from substituted acetylenes: exploitation of molybdenum- and Tungsten based catalysts. Acc Chem Res $17: 51-56$

[47] Akagi K (2009) Helical "polyacetylene: asymmetric polymerization in a chiral liquid-crystal field.” Chem Rev 109:5354-5401

[48] Liu J, Lam JWY, Tang BZ (2009) Acetylenic polymers: syntheses, structures, and functions. Chem Rev 109:5799-5867

[49] Saechtling H (2008) Tworzywa sztuczne-poradnik, WNT, Warszawa

[50] MacDiarmid AG, Heeger AJ (1980) Organic metals and semiconductors: The chemistry of polyacetylene, $(\mathrm{CH}) \mathrm{x}$, and its derivatives. Synth Met 1(2):101-118. https://doi. org/10.1016/0379-6779(80)90002-8
[51] Schopf G, Kossmehl G (1997) Polythiophenes-electrically conductive polymers. Adv Polym Sci. https://doi.org/10.1 007/BFb0111619

[52] Gondek E, Sanetra J, Armatys P, Nizioł J, Chaczaturian K, Danel A (2004) Nowe pirazolochinoliny i ich zastosowanie $\mathrm{w}$ organicznych diodach elektroluminescencyjnych $\mathrm{Z}$ poli(n-winylokarbazolem) w charakterze matrycy. Polimery 49:163-170

[53] Leclerc M, Faid K (1997) Electrical and optical properties of processable polythiophene derivatives: structure-property relationships. Adv Mater 9:1087-1094

[54] Li X-G, Huang M-R, Duan W, Yang YL (2002) Novel multifunctional polymers from aromatic diamines by oxidative polymerizations. Chem Rev 102:2925-3030

[55] Guimard NK, Gomez N, Schmidt CE (2007) Conducting polymers in biomedical engineering. Prog Polym Sci 32:876-921

[56] Fonner JM, Schmidt CE, Ren PA (2010) Combined molecular dynamics and experimental study of doped polypyrrole. Polymer 51:4985-4993

[57] Chaturvedi V, Tanaka S, Kaeriyama K (1992) Preparation of poly(p-phenylene)via processable precursors. J Chem Soc Chem Commun 22:1658. https://doi.org/10.1039/c 39920001658

[58] Gibas E (2016) Polimery I dodatki przewodzạce. Przetwórstwo Tworzyw 6:519-529

[59] Kumar D, Sharma RC (1998) Advances in conductive polymers. Polym J 34(8):1053-1060

[60] Rasmussen SC (2017) The early history of polyaniline: discovery and origins. Substantia 1(2):99-109. https://doi. org/10.13128/substantia-30

[61] Kargirwar SR, Thakare SR, Choudhary MD, Kondawar SB, Dhakate SR (2011) "Morphology and electrical conductivity of self-doping polyanilines synthesized via selfassembly”, process. Adv Mater Lett 2:397-401

[62] Tiwari A, Kumar R, Prabaharan M, Pandey RR, Kumari P, Chaturvedi A, Mishra AK (2010) Nanofibrous polyaniline thin film prepared by plasma-induced polymerization technique for detection of NO2 gas. Polym Adv Technol 21:615-620

[63] Long Y, Chen Z, Wang N, Li J, Wan M (2004) Electronic transport in PANI-CSA/ PANI-DBSA polyblends. Phys B 344:82-87

[64] Lee IS, Lee JY, Sung JH, Choi HJ (2005) Synthesis and electrorheological characteristics of polyaniline-titanium dioxide hybrid suspension. Synth Met 152:173-176

[65] Lövenich W (2014) PEDOT-properties and applications. Polym Sci Ser C 56(1):135-143

[66] Worfolk BJ, Andrews SC, Park S, Reinspach J, Liu N, Toney MF, Bao Z (2015) Ultrahigh electrical conductivity 
in solution-sheared polymeric transparent films. PNAS 112(46):14138-14143. https://doi.org/10.1073/pnas. 1509958112

[67] Yfantis DK, Kakos SI, Lamprakopoulos S, Depountis S, Yfantis CD (2006) Copper electrodeposition on insulators (plastics) using highly conductive polypyrrole films. International conference on environment, ecosystems, and development, Venice, Italy, (pp 20-22)

[68] Hepel M, Chen Y-M, Stephenso R (1996) Effect of the composition of polypyrrole substrate on the electrodeposition of copper and nickel. J Electrochem Soc 143(2):498. h ttps://doi.org/10.1149/1.1836471

[69] Danks TN, Slade RCT, Varcoe JR (2002) Comparison of PVDF- and FEP-based radiation-grafted alkaline anionexchange membranes for use in low temperature portable DMFCs. J Mater Chem 12(12):3371-3373

[70] Zouaoui A, Stéphan O, Carrier M, Moutet JC (1999) Electrodeposition of copper into functionalized polypyrrole films. J Electroanal Chem 474(2):113-122. https://doi.org/ 10.1016/s0022-0728(99)00310-1

[71] Bard AJ, Faulkner LR (2001) Electrochemical methods: fundamentals and applications. John Wiley \& Sons, Hoboken

[72] Nichols RJ, Schröer D, Meyer H (1995) An in situ scanning probe microscopy study of copper electrodeposition on conductive polypyrrole. Electrochim Acta 40(10):1479-1485. https://doi.org/10.1016/00134686(95)00051-f

[73] De Leeuw DM, Kraakman PA, Bongaerts PFG, Mutsaers CMJ, Klaassen DBM (1994) Electroplating of conductive polymers for the metallization of insulators. Synth Met 66(3):263-273. https://doi.org/10.1016/0379-6779(94)900 76-0

[74] Kuciel S, Liber-Kneć A Kompozyty polimerowe na osnowie termoplastów. http://tworzywa.com.pl/Wiadomo $\% \mathrm{C} 5 \%$ 9Bci/Kompozyty-polimerowe-na-osnowie-termoplast $\% \mathrm{C3}$ \%B3w-20974.html. Accessed 18 Mar 2020

[75] Myalski J, Wieczorek J (2009) Właściwości kompozytów polimerowych zawierających cząstki srebra. Kompozyty 9(2):175-180

[76] Hansne A, Hinrichsen EL (1992) Some remarks on percolation. Phys Scr 44:55-61

[77] McLachlan DS (1988) Measurement and analysis of a model dual-conductivity medium using a generalised effective-medium theory. J Phys C Solid State Phys 21(8):1521-1532. https://doi.org/10.1088/0022-3719/21/8/ 025

[78] Newnham RE, Skinner DP, Cross LE (1978) Connectivity and piezoelectric-pyroelectric composites. Mater Res Bull
13(5):525-536. https://doi.org/10.1016/0025-5408(78)901 61-7

[79] Pal R (2007) On the Electrical Conductivity of Particulate Composites. J Compos Materials. https://doi.org/10.1177/ 0021998307076489

[80] Król IA, Redlich G, Obersztyn E, Fortuniak K, Maklewska E, Olejnik M, Bartczak A (2010) Surowce o właściwościach elektroprzewodzạcych w wyrobach wysokospecjalistycznych. Techniczne Wyroby Włókiennicze 18:12

[81] Renishaw (2020) Proszki metali do wytwarzania przyrostowego. https://www.renishaw.pl/pl/proszki-metali-do-wyt warzania-przyrostowego-31457. Accessed 1 July 2020

[82] Mayer P, Kaczmar JW (2008) Właściwości i zastosowania włókien węglowych I szklanych. Tworzywa Sztuczne i Chemia 6:52-56

[83] Olszewski PK, Tarnawski I, Falkiewicz-Dulik M (2017) Synteza i właściwości elektroprzewodzące materiałów na bazie silikonu do zastosowań w przemyśle obuwniczym. Technologia i Jakość Wyrobów 62:4-16

[84] McCunney RJ, Muranko HJ, Long CM, Hamade AK, Valberg PA, Morfeld P (2012) Carbon Black. In: Bingham E, Cohrssen B, Powell CH (eds) Patty's Toxicology. Wiley, Hoboken. https://doi.org/10.1002/0471435139.tox111.pub2

[85] Singh M, Vander Wal R (2018) Nanostructure quantification of carbon blacks. C 5(1):2. https://doi.org/10.3390/c 5010002

[86] Wang M-J, Gray CA, Reznek SR, Mahmud K, Kutsovsky Y (2003) Carbon black. Encycl Polym Sci Technol. http s://doi.org/10.1002/0471440264.pst477

[87] Spahr ME, Gilardi R, Bonacchi D (2017) Carbon black for electrically conductive polymer applications. Polym Polym Compos. https://doi.org/10.1007/978-3-319-28117-9_32

[88] Rozpłoch F, Patyk J, Stankowski J (2007) Graphenes bonding forces in graphite. Acta Physica Polonica 112(3):557-562

[89] Geim AK, Kim P (2008) Carbon wonderland. Sci Am 298(4):90-97. https://doi.org/10.1038/scientificamerican04 08-90

[90] Geim AK (2009) Graphene: status and prospects. Science 324(5934):1530-1534. https://doi.org/10.1126/science. 1158877

[91] Novoselov KS, Jiang D, Schedin F, Booth TJ, Khotkevich VV, Morozov SV, Geim AK (2005) Two-dimensional atomic crystals. PNAS 102(30):10451-10453. https://doi. org/10.1073/pnas.0502848102

[92] Pereira VM, Castro-Neto AH, Peres NMR (2009) Tightbinding approach to uniaxial strain in graphene. Phys Rev B. https://doi.org/10.1103/physrevb.80.045401

[93] Lee C, Wei X, Kysar JW, Hone J (2008) Measurement of the elastic properties and intrinsic strength of monolayer 
graphene. Science 321(5887):385-388. https://doi.org/10. 1126/science. 1157996

[94] Liao L, Lin YC, Bao M, Cheng R, Bai J, Liu Y, Duan X (2010) High-speed graphene transistors with a self-aligned nanowire gate. Nature 467(7313):305-308. https://doi.org/ 10.1038/nature09405

[95] Moser J, Barreiro A, Bachtold A (2007) Current-induced cleaning of graphene. Appl Phys Lett 91(16):163513. h ttps://doi.org/10.1063/1.2789673

[96] Hebda M, Łopata A (2012) Grafen-Materiał Przyszłości. Mechanika, 109(8-M):45-53

[97] Huczko A (2004) Nanorurki Weglowe: Czarne diamenty XXI wieku. Bel Studio, Warszawa

[98] Aqel A, El-Nour KMM, Ammar RAA, Al-Warthan A (2012) Carbon nanotubes, science, and technology part (I) structure, synthesis and characterization. Arab J Chem 5(1):1-23. https://doi.org/10.1016/j.arabjc.2010.08.022

[99] Thostenson ET, Ren Z, Chou TW (2001) Advances in the science and technology of carbon nanotubes and their composites: a review. Compos Sci Technol 61(13):1899-1912. https://doi.org/10.1016/s0266-3538(01 )00094-x

[100] Dobrzańska-Danikiewicz AD, Łukowiec D, Cichocki D, Wolany W (2020) Nanokompozyty złożone z nanorurek węglowych pokrytych nanokryształami metali szlachetnych. http://www.openaccesslibrary.com/vol22015/1.pdf. Accesed 15 Aug 2020

[101] Pietrzak Ł, Jeszka J (2010) Nanokompozyty polilaktyd/ wielościenne nanorurki węglowe - otrzymywanie i właściwości elektryczne. Polimery 55:7-8

[102] Iijima S (2002) Carbon nanotubes: past, present, and future. Physica B 323(1-4):1-5. https://doi.org/10.1016/s0921-45 26(02)00869-4

[103] Yamada T, Namai T, Hata K, Futaba DN, Mizuno K, Fan J, Iijima S (2006) Size-selective growth of double-walled carbon nanotube forests from engineered iron catalysts. Nat Nanotechnol 1(2):131-136. https://doi.org/10.1038/nnano. 2006.95

[104] Burczyk B (1998) Fulereny i nanorurki węglowe. Wydawnictwo Uniwersytetu Wrocławskiego, Wrocław

[105] ASTM D3359-17 Standard test methods for rating adhesion by tape test (2021) https://www.astm.org/Standards/D3359 .htm. Accessed 17 May 2021

[106] Frąckowiak S, Kozłowski M (2010) Polimerowe kompozyty elektroprzewodzace jako materiały o potencjale sensorycznym. Polimery 55:5

[107] Joseph J, Koroth AK, John DA, Sidpara AM, Paul J (2019) Highly filled multilayer thermoplastic/graphene conducting composite structures with high strength and thermal stability for electromagnetic interference shielding applications. J Appl Polym Sci 136(29):47792. https://doi. org/10.1002/app.47792

[108] Bigg DM (1979) Mechanical, thermal, and electrical properties of metal fiber-filled polymer composites. Polym Eng Sci 19(16):1188-1192. https://doi.org/10.1002/pen. 760191610

[109] Biało D (2001) Wytwarzanie kompozytów w procesach metalurgii proszków. Kompozyty 1(1):89-92

[110] Naguchi H, Kakagawa T (2000) Development of high conductivity plastic using short copper fiber. Seikei-Kakou 12(2):111-114

[111] Gardiner FL, Carter EJ (2009) Polymer Electronics - A Flexible Technology. In Michaeli W, Pfefferkorn T, Fragner J (eds) Highly Conductive Plastics-Custom-formulated Functional Materials for Injection Mouldable Electronic Applications. Smithers Rapra Technology, Shawbury, pp 43-56

[112] Flowers PF, Reyes C, Ye S, Kim MJ, Wiley BJ (2017) 3D printing electronic components and circuits with conductive thermoplastic filament. Addit Manuf 18:156-163. https://d oi.org/10.1016/j.addma.2017.10.002

[113] Dupenne D, Lonjon A, Dantras E, Pierré T, Lubineau M, Lacabanne C (2021) Carbon fiber reinforced polymer metallization via a conductive silver nanowires polyurethane coating for electromagnetic shielding. J Appl Polym Sci. https://doi.org/10.1002/app.50146

[114] Islam A, Hansen HN, Tang PT (2017) Direct electroplating of plastic for advanced electrical applications. CIRP Ann 66(1):209-212. https://doi.org/10.1016/j.cirp.2017.04.124

[115] Kim MJ et al (2019) One-step electrodeposition of copper on conductive 3D printed objects. Addit Manuf 27:318-326. https://doi.org/10.1016/j.addma.2019.03.016

[116] Angel K, Tsang HH, Bedair SS, Smith GL, Lazarus N (2018) Selective electroplating of 3D printed parts. Addit Manuf 20:164-172. https://doi.org/10.1016/j.addma.2018. 01.006

[117] Cortes LQ, Lonjon A, Dantras E, Lacabanne C (2014) High-performance thermoplastic composites poly(ether ketone ketone)/silver nanowires: Morphological, mechanical and electrical properties. Elsevier, Amsterdam. https://d oi.org/10.1016/j.jnoncrysol.2014.03.016

[118] Sun Y, Yin Y, Mayers BT, Herricks T, Xia Y (2002) Uniform silver nanowires synthesis by reducing $\mathrm{AgNO} 3$ with ethylene glycol in the presence of seeds and poly(vinyl pyrrolidone). Chem Mater 14(11):4736-4745. https://doi. org $/ 10.1021 / \mathrm{cm} 020587 \mathrm{~b}$

[119] Li J et al (2018) Direct activation of copper electroplating on conductive composite of polythiophene surface-coated with nickel nanoparticles. Compos Part B Eng 
154:257-262. https://doi.org/10.1016/j.compositesb.2018.0 8.019
Publisher's Note Springer Nature remains neutral with regard to jurisdictional claims in published maps and institutional affiliations. 